\title{
Space-Time Analysis of Foot-and-Mouth Disease from 2005 to 2014 among Cattle Populations in Benin: A Retrospective Study
}

\author{
Nestor Noudèkè ${ }^{*}$, Evelyne Houndjè1, Olivier Zannou², Ignace Dotché1, Issaka Youssao1, \\ Souaïbou Farougou ${ }^{1}$ \\ ${ }^{1}$ Département de Production et Santé Animales, Ecole Polytechnique d'Abomey-Calavi, Université d'Abomey-Calavi, Cotonou, \\ République du Bénin \\ ${ }^{2}$ Direction de la Production Animale, Ministère de l'Agriculture, de l'Elevage et de la Pêche, Cotonou, République du Bénin \\ Email: *noudnest@yahoo.fr
}

How to cite this paper: Noudèkè, N., Houndjè, E., Zannou, O., Dotché, I., Youssao, I. and Farougou, S. (2017) Space-Time Analysis of Foot-and-Mouth Disease from 2005 to 2014 among Cattle Populations in Benin: A Retrospective Study. Open Journal of Animal Sciences, 7, 30-44.

http://dx.doi.org/10.4236/ojas.2017.71004

Received: November 17, 2016

Accepted: January 8, 2017

Published: January 11, 2017

Copyright (c) 2017 by authors and Scientific Research Publishing Inc. This work is licensed under the Creative Commons Attribution International License (CC BY 4.0).

http://creativecommons.org/licenses/by/4.0/

c) (†) Open Access

\begin{abstract}
Many cases of foot-and-mouth disease (FMD) are reported every year in Benin. In order to elucidate the epidemiology of this disease, a space-time analysis was carried out in all the 77 municipalities of the country aiming to identify high risk areas as well as risk factors such as season and transhumance on the period of 2005 to 2014 . Data were collected retrospectively from the Directory of Animal Production of Benin. The method of Kulldorff was used with the software SaTScan ${ }^{\mathrm{m}}$ for the spacetime analysis while a script was designed in the software $\mathrm{R}$ to generate new sizes with three different models of transhumance. From 2005 to 2014, 434 foci were recorded. Many outbreaks occurred in August, September and October. This period corresponds to the small rainy season in the South and the rainy season of the North. The municipality of Parakou was regarded as the source FMD outbreaks in Benin because it hosts one of the largest livestock markets in the country and many rivers. It was the municipality at the highest risk. The other municipalities at risk were Nikki, Pèrèrè and Kalaléas well as Karimama (hosting the national parkW), Kouandé and Toucountouna located nearby Pendjari's national park. This study revealed that the spacetime configuration is real and the main factors of persistence and dissemination of FMD virus were national parks, classified forests and the livestock market of Parakou all located in the North. The variation of the number of cattle due to their transhumance from the North to the South did not influence the zones at risk. Therefore, Northern Benin is probably at high risk of FMD.
\end{abstract}

\section{Keywords}

Benin, Foot-and-Mouth Disease, Zone at Risk, Space-Time Analysis,

Transhumance 


\section{Introduction}

For many years, Foot-and-mouth disease (FMD) has been a major preoccupation for veterinary services in the word. It is an infectious disease with zoonotic potentials that affects artiodactyl domestic and wild mammalians including humans [1] [2]. The epidemics are economically devastating in unscathed countries [3]. FMD is endemic and constitutes a major constraint to the international trade for more than two third of OIE (World Organisation for Animal Health) member countries. The risk of introduction of FMD virus limits livestock trades and products from regions where the disease has not been eradicated [4]. Because of its impact on economy and trade, FMD is one of the most important animal diseases in the livestock sector [5].

The perpetual movements of animals and people facilitate the propagation of the virus within a country and between countries. FMD is a trans-boundary disease in West Africa [6]. In some regions where there are no zoo-sanitary reports, the presence or the absence of FMD is sometimes known by the authorities, who, for political, social, and/ or economic reasons opt not to inform the international community [7]. The movements of uncontrolled cattle, the high wildlife population having regular contacts with livestock and the lack of willingness to control FMD among decision makers, are some of the many factors that encourage the persistence of this disease [8]. The lack of infrastructures and human resources in many developing countries hinders the control of the propagation of the disease [9]. In some African regions, particularly West Africa, the lack of knowledge on the epidemiology of FMD affects the effective control of this disease. It is endemic and new foci are recorded regularly without a clear picture on its mechanism of transmission [10].

Frequent FMD outbreaks occur in Benin like the one reported during the dry season of 1990-1991 [11]. Houndjè [12] carried out a study in the departments of Benin from 2003 to 2006 with the spatial model of Besag and space-time model of Wallerto to determine the space and space-time distribution of FMD as well as the space-time distribution of its relative risk. He concluded that all departments of Benin present high to very high relative risks of FMD. For a better understanding of the epidemiology of FMD for improved control measures in Benin, there is an urgent need to evaluate the space-time distribution of the risk at municipalities' level. Moreover, transhumance has often been incriminated as an important risk factor of FMD while no study was conducted to prove this.

The present retrospective study aimed to identify at municipality' level, the areas at high risk of FMD on the period of 2005 to 2014. It also aimed to conduct an analysis of risk factors of FMD such as season and transhumance. The null hypothesis is that FMD is randomly distributed in all municipalities of Benin. The results will lead to recommendations for reducing the economic impact associated with this disease.

\section{Material and Methods}

\subsection{Study Area}

The whole country has been taken into account. The Republic of Benin is a West African country located between $6^{\circ} 10^{\prime} \mathrm{N}$ and $12^{\circ} 25^{\prime} \mathrm{N}$ and between $0^{\circ} 45^{\prime} \mathrm{E}$ and $3^{\circ} 55^{\prime} \mathrm{E}$. It covers a total surface of $114.763 \mathrm{~km}^{2}$ and is limited at the North-west by Republic of 
Burkina Faso, the North by Republic of Niger, the West by Republic of Togo, the East by the Federal Republic of Nigeria and the South by the Atlantic Ocean. It is administratively constituted of 4 hierarchical levels that are: departments, municipalities, districts and villages or wards. Benin counts 12 departments, 77 municipalities, 546 districts and 3557 villages/wards.

Benin is part of the inter-tropical zone. Following the latitude, rainy seasons are combined in different manners to define particular rainfall regimes. In the South of the parallel $7^{\circ} 45^{\prime}$, the bimodal regime comprises four seasons of which: a big rainy season (April to July), a small dry season (August to September), a small rainy season (October to November) and a big dry season (December to March). In the North of the parallel $8^{\circ} 30^{\prime}$, it's a unimodal type of regime with two seasons: one dry and one rainy. The dry season covers November to early May and the rainy season ranges from May to October. But with the influence of climate change, the dry season is becoming longer than the rainy in the country.

The size of livestock of the country was estimated in 2009 at 1,954,000 cattle, 2,314,000 small ruminants, 354,000 pigs and $15,500,000$ poultries. The estimated cost was F CFA 235.78 billion. The national cattle population is concentrated essentially in the departments of the North (Borgou, Alibori, Atacora, Donga), that possess $85 \%$ of the national size which is about $1,200,000$ heads. Since the drought of $70 \mathrm{~s}$ and $80 \mathrm{~s}$, transhumance from bordering countries (Niger, Nigeria and Burkina-Faso) has increased significantly with about 200,000 cattle and 17,000 heads of sheep and goats in the dry seasons of 1994-1995. The pastoral and agro-pastoral production systems adopted in these areas encourage a transhumant mode of husbandry. This leads to a space management characterized by day grazing with two types of transhumance. The small transhumance practiced in rainy seasons mainly during harvestings.

The big transhumance practiced in dry seasons for about six months. At the end of the dry season, with the insufficiency of pasture, some breeders take the risk to illegally penetrate the national parks. The official areas reserved for transhumance are Couffo, Southern Zou, Northern Atlantic and the plateau of Bonou in Ouémé. Classified forests of these areas are the places of predilection of breeders, who are mostly of Peulh ethnic group.

\subsection{Source and Type of Data}

Data were provided by the Directory of Animal Production (DAP) which operates under the Ministry of agriculture, livestock and fisheries. These data were collected in the field by veterinarians present in each of the 77 municipalities of the country on a period of 10 years from 2005 to 2014. Once collected, data were transferred to the DAP every month. The current study included only data concerning FMD in cattle of all breeds. They contained information on the number of cattle presenting clinical signs, number of infected herds and number of FMD foci.

In addition, data on the cattle size in each of the 77 municipalities were collected on the same period of 2005 to 2014. Regarding transhumance, reports and statistical records of the DAP were consulted to probe information on the departing and hosting municipalities, as well as the departure and return periods. The geographical coordi- 
nates of municipalities were obtained using the software Manifold system.

\section{Data Analyses}

\subsection{Space-Time Analysis}

Space-time analyses based on Poisson distribution were performed using SaTScan ${ }^{\mathrm{rx}}$, a software of statistic, space, time and space-time analyses [13] following the method described by [14].

For space analysis, a circle was made around the whole study area. Around every geographical coordinate, there was a circle with a radius that changes continuously by including neighbouring geographical centres. This continued until the circle contained a certain number of geographical centres situated between 0 and a percentage of the total number of geographical coordinates of the centre of the concerned municipality. This percentage is a limit defined for the analysis. For the present study, these limits were $50 \% ; 25 \%$ and $10 \%$. Areas at risk (clusters) of small sizes are obtained when this percentage decreases.

Once the program is launched, a number of different circles are created containing each a municipality or a group of neighbouring municipalities. Each of these circles was a potential cluster of area at risk of FMD. For each of the formed circles, while including new geographical centres and stretching toward the limit of the percentage, the space analysis calculates the likelihood of the number of cases observed inside and outside the circle. The circle with the maximum likelihood is defined as the most probable cluster. This means that this circle is the one for which the likelihood that the area at risk is due to chance is the lowest. For every circle, the method makes a comparative test between the null and the alternative hypotheses. According to the null hypothesis, the risk for an animal to be infected by FMD is the same in all municipalities, i.e. in all circles. While the alternative hypothesis stipulates that there is at least a circle (a municipality or a group of municipalities) for which the risk of infection by FMD virus is higher inside the circle than outside. Therefore, when the likelihood of every circle is calculated and compared to the one of the other circles, the circle with the highest likelihood is obtained. Then the municipalities that are inside this circle form the most probable cluster having the highest risk for an animal to be infected by FMD.

The P-Value of the analysis (Probability to accept or reject the null hypothesis) was obtained through the test of hypothesis of Monte Carlo where the null hypothesis for the absence of clusters is rejected at a critical probability of 0.05 . The program generated the likeliest cluster with its corresponding P-Value. If other clusters that have no municipalities in common with the likeliest cluster are identified, they were considered as secondary clusters and were displayed with their corresponding P-Values. When the cylinder moves in a given region, the time analysis, determines the intervals of time corresponding to the periods in which an abnormal increase of the number of FMD cases are observed as compared to other regions. The combination of these different data provided the result of the space-time analysis.

This method was applied in the present study area for every month from 2005 to 2014. 


\subsection{Analysis of Transhumance}

Simulations of transhumance were performed with the software $\mathrm{R}$ software version 3.1.2 [15]. The objective was to generate new cattle sizes per municipality according to their departures and arrivals. These new sizes were introduced in the software SaTScan ${ }^{\text {tw }}$ for a new space-time analysis. Three models of simulation were made. A script was drafted for every simulation model based on the cycle of transhumance during one year. Therefore, the country was dived in four big zones: the extreme North, the North, the Centre and the South. Since the movement of transhumance is from the North to the South and the return from the South to the North, the municipalities in the part defined as South were those where the movements stopped. The months in which animals proceed progressively to the South followed by their progressive return to the North were thereafter defined. Based on the data obtained from the Directory of Animal Production [16] [17] [18] [19] which shows that about $10 \%$ of cattle populations in the North go in transhumance every year, this percentage was applied on the cattle size of the extreme North in the first simulation model. In the second simulation model, on top of the $10 \%$ of the cattle population of the extreme North that leave for transhumance in a given time, $10 \%$ of the population of the North that also go in transhumance was added. Finally, the third simulation model was made based on the months in which the number of cases of FMD reaches its peak in the Centre and the South and the $10 \%$ of the transhumant population was considered as coming from the North (Extreme North and all the North).

The script was used to get a proportional distribution of the transhumant population in the different municipalities where they passed through. This also revealed how the local cattle populations of the departure and arrival municipalities vary annually. Some municipalities in the South where transhumant cattle do not pass had their cattle size constant all year round. Once all these points were considered, the script was turned in the software R, for each year from 2005 to 2014 in all the simulation models. This was how for every year, new local and monthly cattle sizes were generated and introduced in the software SaTScan ${ }^{\text {tx }}$. The number of cases and geographical coordinates of the centroids remained unchanged. In the three simulation models, the rates of transhumant populations were increased from $10 \%$ to $15 \%, 20 \%, 30 \%, 40 \%$ and $50 \%$ in order to assess whether risky clusters could be detected in regions other than the North. Tables 1-3 present the different simulation models.

Furthermore, the software of geographical information system Manifold ${ }^{\bullet}$ System (http://www.manifold.net) was used to:

$\sigma$ visualize municipals that are affected by FMD according to the year;

$\sigma$ generate Cartesian and decimal coordinates of the centroids;

$\checkmark$ visualize the clusters.

The Map of Benin was obtained from the website of DIVA-GI [20] (Figure 1).

\section{Results}

From 2005 to 2014, 434 foci were recorded. Figure 2 shows the evolution of the number of foci according to months. The number of times that municipals were affected varied from once to 46 times. It was observed that: 
Table 1. First simulation model with $10 \%$ of the cattle population of the extreme North.

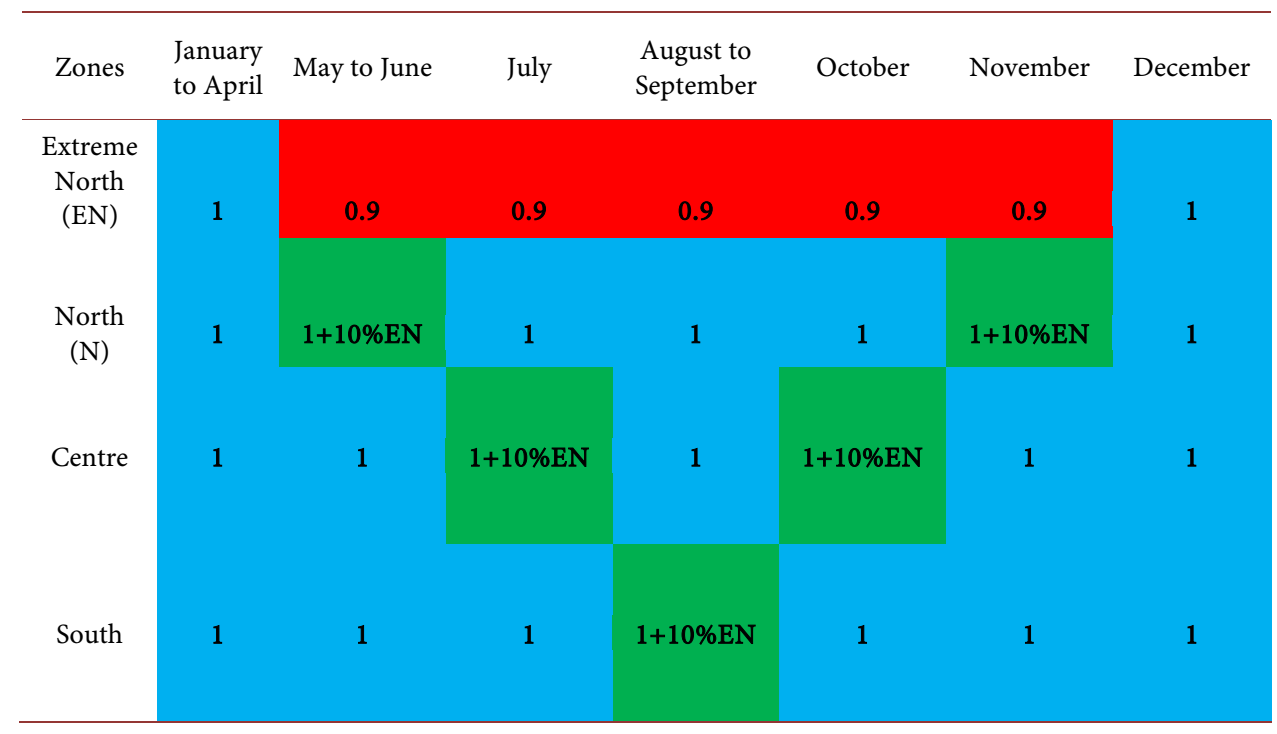

Period without variation of cattle size due to transhumance.

Period with $10 \%$ decrease of the cattle size due to transhumance in Extreme North. $\square$ Period with $10 \%$ decrease of the cattle size due to transhumance in Extreme North.

Table 2. Second simulation model with $10 \%$ of the cattle population of extreme North plus $10 \%$ from the North.

\begin{tabular}{|c|c|c|c|c|c|c|c|}
\hline Zones & $\begin{array}{l}\text { January } \\
\text { to April }\end{array}$ & $\begin{array}{l}\text { May to } \\
\text { June }\end{array}$ & July & $\begin{array}{l}\text { August to } \\
\text { September }\end{array}$ & October & November & December \\
\hline $\begin{array}{c}\text { Extreme } \\
\text { North } \\
\text { (EN) }\end{array}$ & 1 & 0.9 & 0.9 & 0.9 & 0.9 & 0.9 & 1 \\
\hline $\begin{array}{l}\text { North } \\
(\mathrm{N})\end{array}$ & 1 & $\begin{array}{c}1+10 \% \\
\text { EN }\end{array}$ & 0.9 & 0.9 & 0.9 & $1+10 \%$ EN & 1 \\
\hline Centre & 1 & 1 & $\begin{array}{c}1+10 \% \mathrm{EN} \\
+10 \% \mathrm{~N}\end{array}$ & 1 & $\begin{array}{c}1+10 \% \mathrm{EN} \\
+10 \% \mathrm{~N}\end{array}$ & 1 & 1 \\
\hline Centre & & & & $1+10 \% \mathrm{EN}$ & & & \\
\hline South & 1 & 1 & 1 & $+10 \% \mathrm{~N}$ & 1 & 1 & 1 \\
\hline
\end{tabular}

Period without variation of cattle size due to transhumance. Period with $10 \%$ decrease of the cattle size due to transhumance in Extreme North. $\square$ Period with 10\% decrease of the cattle size due to transhumance in the North. $\square$ Period of transhumant cattle hosting.

$\sigma$ all municipalities of the North (those from the departments of Atacora, Alibori, Borgou and Donga) were affected at least once;

$\sigma$ in the South (departments of Mono, Couffo, Atlantic, Litoral, Ouémé and Plateau), 16 municipalities out of 35 were affected;

$\sigma$ in the Centre(departments of the Zou and Collines), 10 municipalities were affected out of 15 .

Overall, 53 municipalities were affected at least once by FMD in the study period out of the 77 of the country. 
Table 3. Third simulation model with $10 \%$ of the population of extreme North and all the North.

\begin{tabular}{cccccc}
\hline Zones & $\begin{array}{c}\text { January to } \\
\text { March }\end{array}$ & April & May to July & $\begin{array}{c}\text { August to } \\
\text { November }\end{array}$ & December \\
\hline North (N) & 1 & 0.9 & 0.9 & 0.9 & 1 \\
Centre & 1 & $1+10 \% \mathrm{~N}$ & 1 & $1+10 \% \mathrm{~N}$ & 1 \\
& & & & & 1 \\
\hline
\end{tabular}

Period without variation of cattle size due to transhumance. Period with $10 \%$ decrease of the cattle size due to transhumance in Extreme North. $\square$ Period of transhumant cattle hosting.

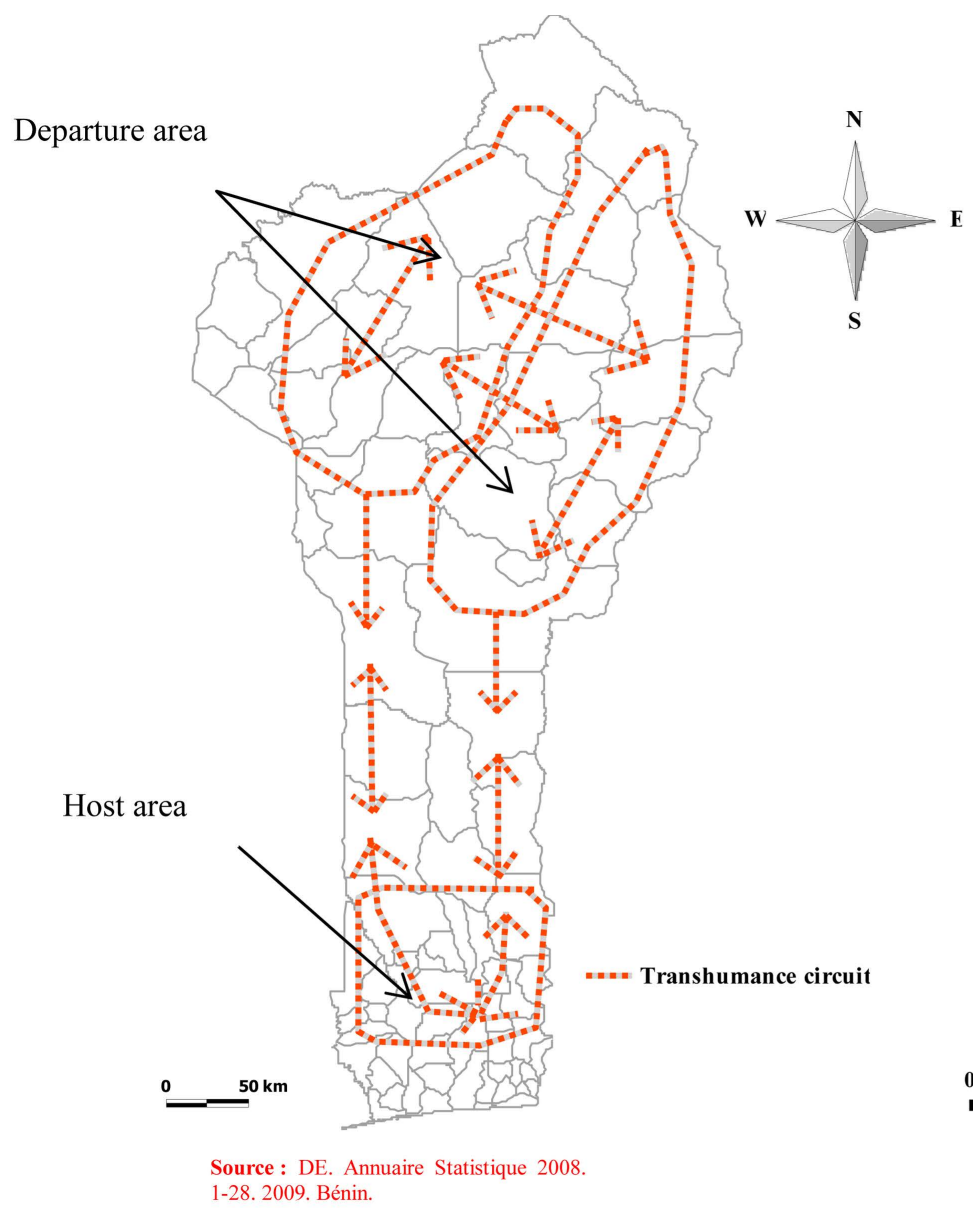

(a)

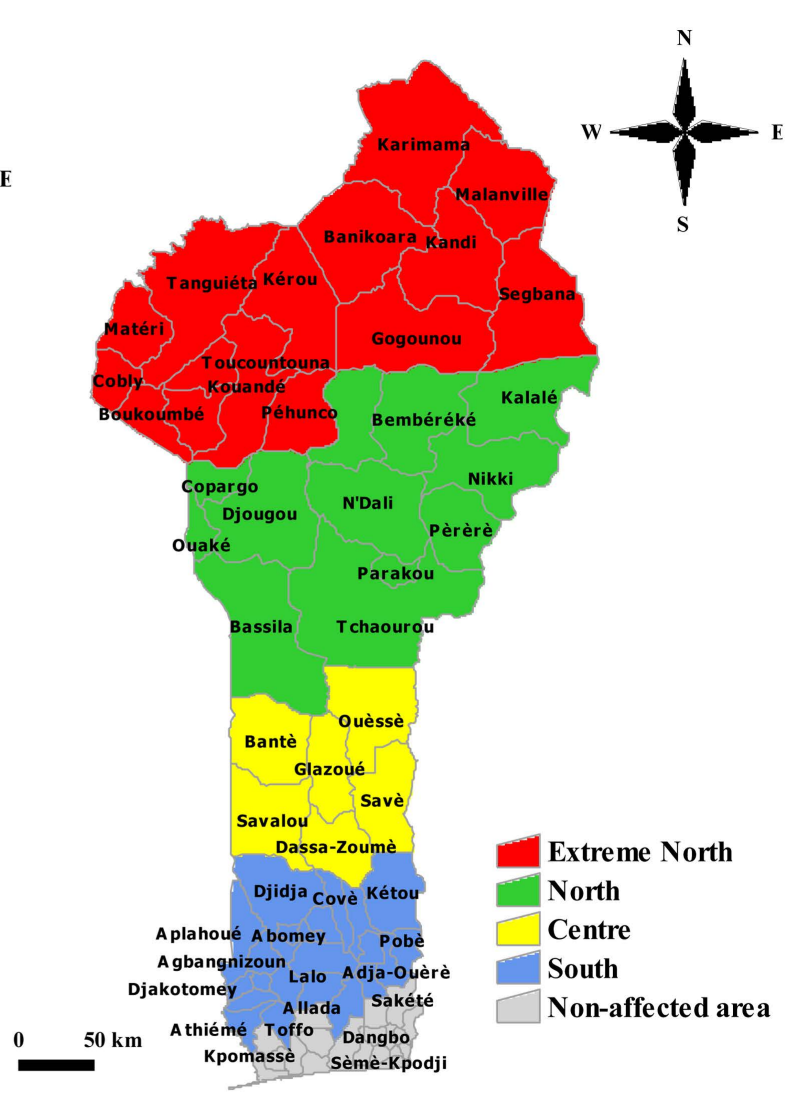

(b)

Figure 1. Main circuits of transhumance (a) and distribution of Beninese municipalities according to transhumance simulations (b).

\subsection{Space-Time Analysis}

All clusters were statistically significant $\left(\mathrm{P}-\right.$ Value $\left.<10^{-17}\right)$ and located in the North (Figure 3(c)). The main cluster was Parakou situated in the department of Borgou, 


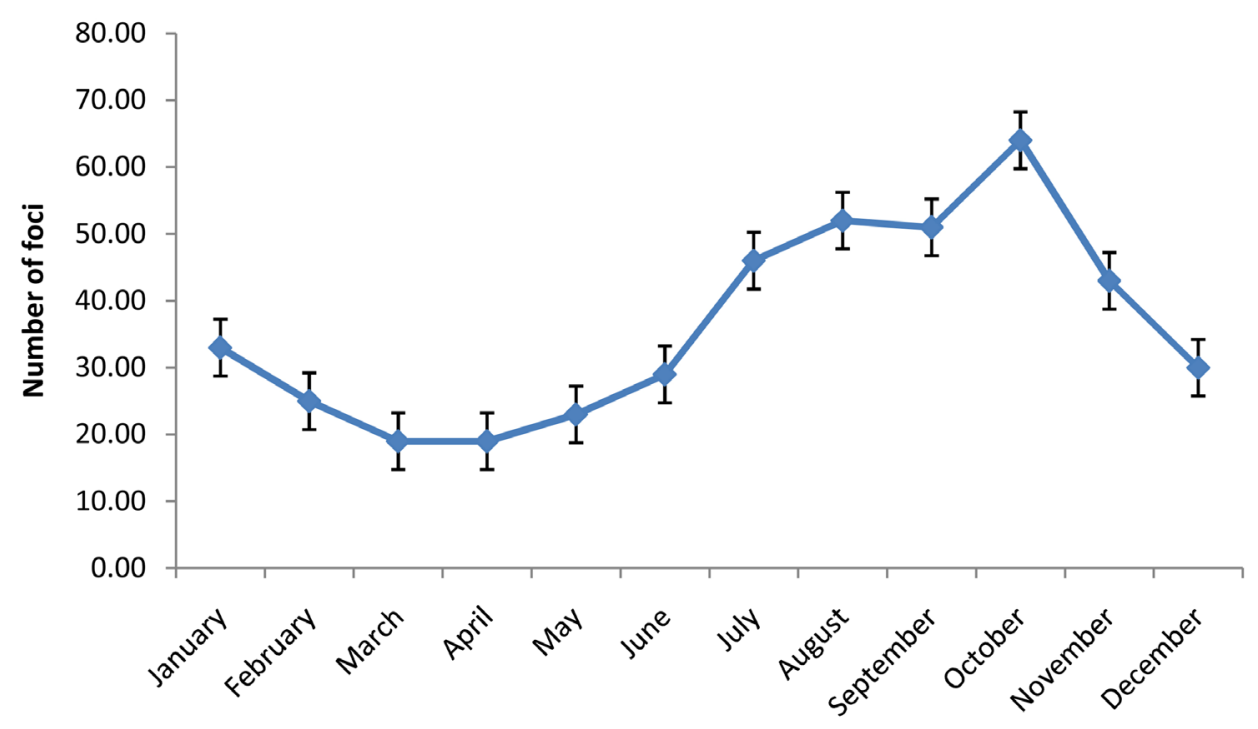

Figure 2. Evolution of the number of foci according to the months from 2005-20014.

followed by three secondary clusters such as: Nikki-Pèrèrè-Kalalé (in Borgou); KouandéToucountouna (in Atacora) and Karimama (in Alibori) (Table 4). The main cluster was observed between March $1^{\text {st }}, 2006$ and December $31^{\text {st }}, 2010$ with a relative risk of 56.67. This means that cattle from this municipal (Parakou) are 56.67 times more at risk to be infected than animals from elsewhere in the country. A proximity of some clusters with natural reserves was also noted (Figure 3(d)).

The use of the software SaTScan ${ }^{\text {Tx }}$ with elliptic basis also revealed that the main cluster was Parakou. But with only one secondary cluster that was Ségbana-Nikki-KalaléPèrèrè. When the same software was used with a circular basis at $25 \%$, it revealed that the previously obtained clusters at $50 \%$ were still present but Nikki-Pèrèrè-Klalé became the main cluster, whereas N'dali-Parakou-Sinendé was the secondary cluster. Similarly, when the software is turned with an elliptic basis at $25 \%$, there was a stability of the obtained clusters. Nevertheless, with a circular basis at $10 \%$, there was one main cluster with 12 secondary clusters. In all the cases, it was noticed that whether the basis is circular or elliptic, a stability of the clusters was detected with a maximum of $50 \%$ of the centroids.

From 2005 to 2014, there was a total of 434 declarations of FMD infections in Benin. The largest numbers of cases were recorded in August, September and October as shown in Figure 2. These months correspond more or less to the small dry season in the South, while in the North, it stretches toward the end of the rainy season.

\subsection{Analysis of Transhumance}

First simulation model: it revealed same clusters as those obtained without considering transhumance (Table 4). The periods of occurrence, number of cases and the P-Values were the same; but some values (cattle population, number of expected cases, reports, relative risk, Log likelihood ratio) changed. In particular, Parakou, Nikki, Pèrèrè and Kalalé presented a reduction of the relative risk while, Kouandé, Toucountouna andKarimama had an increased relative risk. 
Table 4. Results of the space-time analysis.

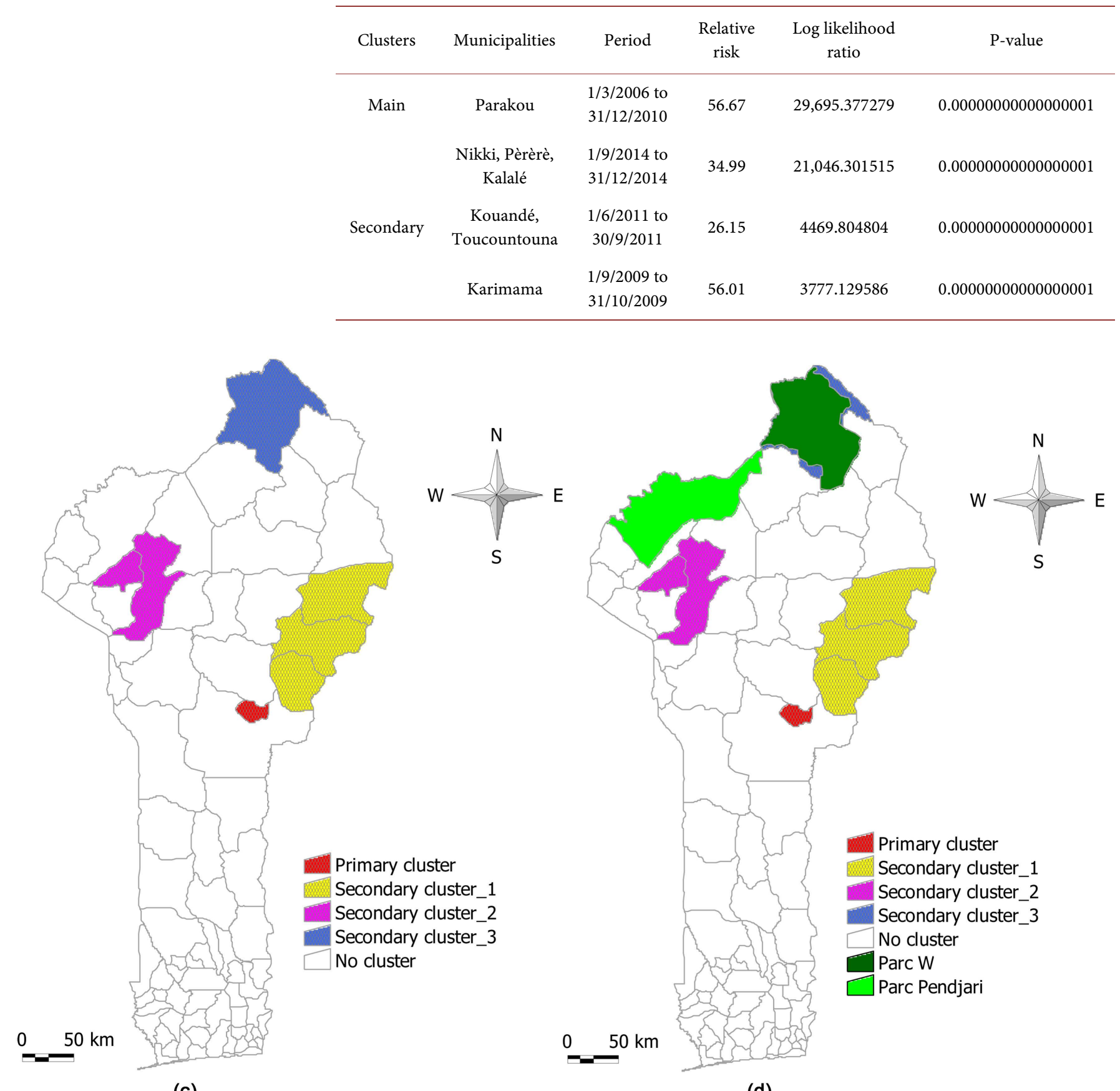

(c)

(d)

Figure 3. Results of the space-time analysis (c) and localization of the clusters in relation to the location of the two national parks of the country (d).

Second simulation model: the trends were similar to those observed with the first simulation model but only the main cluster didn't have an increased relative risk.

Third simulation model: trends were similar to those of the first model but all clusters had increased relative risks.

The variation of the rate of transhumant populations from $10 \%$ to $50 \%$ with the first and the second simulation models revealed that all detected clusters (main or secon- 
dary) didn't vary as compared to the situation of non-transhumance. With the third simulation model, a rate of transhumant population of $50 \%$ was need to get two secondary clusters formed by the municipalities of Bohicon, Zangnanado, Abomey, Zogbodomey, Agbangnizoun, Covè, Klouékanmey, Tori-Bossito, Lalo, Za-Kpota, Djidja, Ouinhi, Toviklin, Aplahoué, Bonou, Zè, Allada, Dogbo, Djakotomey, Bopa and AdjaOuèrèfor the first and Kétou municipality for the second. These municipalities are the transhumance hosting areas.

Tables 5-7 show the results of the space-time analysis of the transhumance simulation models.

Table 5. Result of the space-time analysis with the first transhumance simulation model at $10 \%$.

\begin{tabular}{|c|c|c|c|c|}
\hline Clusters & Municipalities & Periods & Relative risk & Log likelihood ratio \\
\hline Main & Parakou & $\begin{array}{l}1 / 3 / 2006 \text { to } \\
31 / 12 / 2010\end{array}$ & 54.91 & $29,384.102947$ \\
\hline \multirow{3}{*}{ Secondary } & Nikki, Pèrèrè, Kalalé & $\begin{array}{l}1 / 9 / 2014 \text { to } \\
31 / 12 / 2014\end{array}$ & 33.74 & $20,748.846023$ \\
\hline & $\begin{array}{c}\text { Kouandé, } \\
\text { Toucountouna }\end{array}$ & $\begin{array}{l}1 / 6 / 2011 \text { to } \\
30 / 9 / 2011\end{array}$ & 29.06 & 4668.512495 \\
\hline & Karimama & $\begin{array}{l}1 / 9 / 2009 \text { to } \\
31 / 10 / 2009\end{array}$ & 62.23 & 3906.184087 \\
\hline
\end{tabular}

Table 6. Result of the space-time analysis with the second transhumance simulation model at $10 \%$.

\begin{tabular}{ccccc}
\hline Clusters & Municipalities & Periods & Relative risk & Log likelihood ratio \\
\hline \multirow{2}{*}{ Main } & Parakou & $1 / 3 / 2006$ to & 56.45 & $29,658.009341$ \\
& & $31 / 12 / 2010$ & & \\
& Nikki, Pèrèrè, Kalalé & $1 / 9 / 2014$ to & 35.41 & $21,143.184799$ \\
& & $31 / 12 / 2014$ & & \\
Kecondary & Kouandé, & $1 / 6 / 2011$ to & 29.06 & \\
& Toucountouna & $30 / 9 / 2011$ & & 3668.512687 \\
& & $1 / 9 / 2009$ to & 62.23 & \\
& Karimama & $31 / 10 / 2009$ & & \\
\hline
\end{tabular}

Table 7. Result of the space-time analysis of the third transhumance simulation model at $10 \%$.

\begin{tabular}{|c|c|c|c|c|}
\hline Clusters & Municipalities & Periods & Relative risk & Log likelihood ratio \\
\hline Main & Parakou & $\begin{array}{l}1 / 3 / 2006 \text { to } \\
31 / 12 / 2010\end{array}$ & 60.87 & $30,401.221432$ \\
\hline \multirow{3}{*}{ Secondary } & Nikki, Pèrèrè, Kalalé & $\begin{array}{l}1 / 9 / 2014 \text { to } \\
31 / 12 / 2014\end{array}$ & 37.80 & $21,674.554168$ \\
\hline & $\begin{array}{c}\text { Kouandé, } \\
\text { Toucountouna }\end{array}$ & $\begin{array}{l}1 / 6 / 2011 \text { to } \\
30 / 9 / 2011\end{array}$ & 29.06 & 4668.512988 \\
\hline & Karimama & $\begin{array}{l}1 / 9 / 2009 \text { to } \\
31 / 10 / 2009\end{array}$ & 62.23 & 3906.184407 \\
\hline
\end{tabular}




\section{Discussion}

The main cluster was the municipality of Parakou and this persisted for over four years from March 1 $1^{\text {st }}, 2006$ to December $31^{\text {st }}, 2010$. Throughout this period, there was an abnormal increase of the number of cases of FMD. Parakou hosts one of the largest livestock markets in the North and animals from other primary markets are often driven toward this municipality where beef that is used to supply other big cities of the country are routinely traded. Farmers from Niger, Burkina Faso and Nigeria are also found in this interface to buy and sell cattle. This confers to Parakou the status of transit city at the heart of regional cattle trade. This melting-pot could be at the origin of the frequent FMD outbreaks. According to [21], cattle markets are among factors that encourage the propagation of FMD. Furthermore, there are various streams or effluents of Okpara River that pass through Parakou. These streams are subdivided endlessly and irrigate important grazing spaces and also used by animals for drinking. All this provokes a gathering of many animals from everywhere. This situation could facilitate the transmission of FMD because some transmission foci were reported among impala populations along rivers in South Africa [22]. Since direct contact is the main route of transmission of FMD according to [6], contacts between cattle from various horizons in the market of Parakou can contribute to the widespread of the disease among cattle. The market and the rivers could therefore be considered as the source of persistence of FMD in Parakou.

The first secondary cluster was Nikki-Kalalé-Pèrèrè. In this region, natural rivers are seasonal [23]. Most of FMD cases were recorded in August, September and October; being the end of the rainy season in the North. Therefore animals gathering around these rivers in such period could be a cause of outbreaks. The second secondary cluster made of Kouandé and Toucountouna municipalities was located close to Pendjari' park (Figure 3(d)). This park is shared between Benin, Togo and Burkina-Faso. The third and last cluster that is Karimama municipal hosts the park W (Figure 3(d)). This latter is shared between Burkina-Faso; Niger and Benin. Studies of [6] revealed that the park W is recognized as a primary source of FMD virus. Although it is forbidden, some farmers often bring their cattle inside these reserves for grazing. The contamination of their animals by some wild species, mainly buffalos, is therefore very likely. Several studies reported the key role that wildlife plays in the persistence and transmission of FMD virus [24]-[32]. About 60 to 70 wild animal species were revealed as sensitive to natural or experimental FMD infection and many times, FMD virus has been isolated from these animals in which they mostly live as commensals. A number of these wild species are involved in the contamination of livestock, in particular those that are sometimes in contact with them [33]. This contact can occur during grazing or around the water sources. Natural reserves of the North could therefore be responsible for the persistence of the virus. This view contradicts a part of the results of Houndjè [12] who mentioned that Northern Beninis not a high risk area for FMD. However, further serological investigations must be made to clarify it.

Animals that are clinically healed or those in incubation play an important role in the persistence and transmission of the virus within herds [6]. In Mali, a country located in the same geographical area as Benin, it is likely that cattle are more involved than wild 
animals in the persistence of FMD, since clinically healed animals are not always withdrawn from the herds. Therefore, subclinical infections constitute serious reservoirs of FMD virus. The possible role of cattle that carry the virus in the transmission of FMD was considered because many outbreaks occurred after the introduction of new animals in the herds [10]. Studies show that cattle can carry the FMD virus for about two years and half [34].

Small ruminants also play an important role in the epidemiology and the transmission of FMD. In these species, FMD is barely diagnosed because the infected sheep do not show typical clinical signs [35] [36]. In Benin, farmers are used to keep clinically healed animals (sometimes even sick) together with healthy animals. It is also frequent to find at the same time a cattle keeper having a herd of small ruminants as described by Maddur [37]. Furthermore, newly acquired animals (purchased, keeping for a colleague...) are not quarantined before their introduction in the herd. This situation could also explain the fact that the main cluster was the municipality of Parakou with its livestock market where many animals are mixed in a questionable sanitary condition.

August, September and October where transhumant animals were all found in the Centre and the South correspond to the months where high numbers of sick animals were recorded in the whole country. Despite this situation, the newly generated cattle populations didn't lead to the detection of new clusters elsewhere than in the North. Following the variation of the rate of transhumant populations, it was with the third model at $50 \%$ that a secondary cluster was observed in the Centre and in the South of the country. This percentage was actually too high. In addition to the reports of the Directory of Animal Production that showed that about $10 \%$ of animals in the North of Benin go in transhumance, Konkobo [38] underlined that in Burkina-Faso this percentage is $11.9 \%$. Therefore, the high FMD cases observed during some months in the South was not due to the increase of cattle population induced by transhumance. It was rather a situation caused by a higher risk, which contradicts the results of some previous studies [12] [38]. The study also revealed that transhumance is practiced from the North towards the South in dry seasons while all zones at high risk are located in the North at the end of rainy seasons. It is clear that transhumance doesn't transform the host areas in high risk zones. The survival of FMD virus in natural conditions depends on UV lights and the humidity of the area. However, the fact that animals pass thought the North to the South during transhumance constitutes an important factor of dissemination of the virus in the nature. Infected herds that practice transhumance can transmit the infection to other herds long before the diagnosis of the disease can be established [35]. Moreover, the stress caused by the displacement of animals towards new sites is a mechanism that can trigger an outbreak following a dysfunction of the immune system capable to provoke the excretion of the virus by carrier animals [39].

\section{Conclusions}

From 2005 to 2014, the months of August, September and October were the periods of high occurrence of FMD. The main factors of persistence and dissemination of the virus were natural reserves and the livestock market of Parakou all located in the North. 
These main factors could be associated with other risky behaviours of cattle farmers. The variation of cattle populations due to transhumance from the North to the South did not change high risk areas. The North of the country is therefore more at risk and carrier animals or those having the virus in incubation could be part of factors responsible for the persistence of FMD virus.

Thus, for better control of foot-and-mouth disease in Benin, cattle's gathering for sale in Parakou municipality should be better controlled from their origin. The movements of cattle around natural reserves must be strictly regulated. These preventive actions must be implemented before the critical period from August to September.

Further studies are required to identify the wild species which is the most responsible carrier of the virus and to clarify the periods and transmission mechanisms of the disease to cattle. The present study showed that the space-time configuration of FMD is real and demonstrates that national parks, rivers and cattle markets play an important role in the persistence of FMD virus in Benin. Other investigations are needed to identify the primary and secondary zones of infections. The limitations of this study are in the numbers of livestock because the census is not done on a periodic basis. Besides, the technique used in the present study to monitor the effect of increased cattle populations on the detection of zones at risk can be revised and improved by new approaches.

\section{References}

[1] Grubman, M.J. and Baxt, B. (2004) Foot-and-Mouth Disease. Clinical Microbiology Reviews, 17, 465-493. https://doi.org/10.1128/CMR.17.2.465-493.2004

[2] Hyslop, N.S. (1973) Transmission of the Virus of Foot and Mouth Disease between Animals and Man. Bulletin of the World Health Organization, 49, 577-585.

[3] Ferguson, N.M., Donnelly, C.A. and Anderson, R.M. (2001) The Foot-and-Mouth Epidemic in Great Britain: Pattern of Spread and Impact of Interventions. Science, 292, 11551160 .

[4] Vosloo, W., Bastos, A.D., Sangare, O., Hargreaves, S.K. and Thomson, G.R. (2002) Review of the Status and Control of Foot and Mouth Disease in Sub-Saharan Africa. Revue Scientifique et Technique, 21, 437-449. https://doi.org/10.20506/rst.21.3.1349

[5] Kreienbrock, L., Willms, H., Selhorst, T., Ovelhey, A., Haas, L., Moennig, V. and Kramer, M. (2010) [Transmission Risk for Foot-and-Mouth-Disease in an Animal-Densed Region in Germany-Results from an Expert Survey]. Berliner und Münchener Tierärztliche Wochenschrift, 123, 89-95.

[6] Couacy-Hymann, E., Aplogan, G.L., Sangare, O., Compaore, Z., Karimu, J., Awoueme, K. A., Seini, A., Martin, V. and Valarcher, J.F. (2006) Retrospective Study of Foot and Mouth Disease in West Africa from 1970 to 2003. Revue Scientifique et Technique, 25, 1013-1024. https://doi.org/10.20506/rst.25.3.1709

[7] Garabed, R.B., Perez, A.M., Johnson, W.O. and Thurmond, M.C. (2009) Use of Expert Opinion for Animal Disease Decisions: An Example of Foot-and-Mouth Disease Status Designation. Preventive Veterinary Medicine, 92, 20-30. https://doi.org/10.1016/j.prevetmed.2009.06.010

[8] Kivaria, F.M. (2003) Foot and Mouth Disease in Tanzania: An Overview of Its National Status. Veterinary Quarterly, 25, 72-78. https://doi.org/10.1080/01652176.2003.9695147

[9] Perry, B.D. and Rich, K.M. (2007) Poverty Impacts of Foot-and-Mouth Disease and the Poverty Reduction Implications of Its Control. Veterinary Record, 160, 238-241. https://doi.org/10.1136/vr.160.7.238 
[10] Sangare, O., Dungu, B. and Bastos, A.D. (2004) Foot and Mouth Disease in Mali: The Current Situation and Proposed Control Strategies. Revue Scientifique et Technique, 23, 863872. https://doi.org/10.20506/rst.23.3.1525

[11] Dehoux, J.P. and Hounsou-Ve, G. (1991) Outbreak of Foot-and-Mouth Disease in Northern Benin during the 1990-1991 Dry Season. Revue d'Elevage et de Médecine Vétérinaire des Pays Tropicaux, 44, 261-262.

[12] Houndjè, E.M.B. (2007) Approche bayésienne spatio-temporelle des cas cliniques de fièvre aphteuse au Bénin de 2003-2006. IMTA. Thèse de Master en Santé Animale Tropicale 64, $1-18$.

[13] Kulldorff, M. (2011) SatScan. USA. http://www.satscan.org

[14] Kulldorff, M. and Nagarwalla, N. (1995) Spatial Disease Clusters: Detection and Inference. Statistics in Medicine, 14, 799-810. https://doi.org/10.1002/sim.4780140809

[15] R Project (2010) R Environment. USA. http://www.cranr-project.org

[16] DE (2009) Rapport Annuel. Bénin, 1-50.

[17] DE (2008) Annuaire Statistique. Bénin, 1-28.

[18] DE (2007) Rapport Annuel. Bénin, 1-58.

[19] DE (2006) Rapport Annuel. Bénin, 1-54.

[20] DIVA-GIS (2011) Carte administrative du Bénin. http://www.diva-gis.org/datadown

[21] Bronsvoort, B.M., Nfon, C., Hamman, S.M., Tanya, V.N., Kitching, R.P. and Morgan, K.L. (2004) Risk Factors for Herdsman-Reported Foot-and-Mouth Disease in the Adamawa Province of Cameroon. Preventive Veterinary Medicine, 66, 127-139. https://doi.org/10.1016/j.prevetmed.2004.09.010

[22] Vosloo, W., Knowles, N.J. and Thomson, G.R. (1992) Genetic Relationships between Southern African SAT-2 Isolates of Foot-and-Mouth-Disease Virus. Epidemiology and Infection, 109, 547-558. https://doi.org/10.1017/S0950268800050536

[23] ANCB (2011) Monographie de la commune de Sinendé. http://www.ancb-benin.org/pdc-sdac-monographies/SDAC/sinendepdf

[24] Anderson, E.C., Foggin, C., Atkinson, M., Sorensen, K.J., Madekurozva, R.L. and Nqindi, J. (1993) The Role of Wild Animals, Other than Buffalo, in the Current Epidemiology of Foot-and-Mouth Disease in Zimbabwe. Epidemiology and Infection, 111, 559-563. https://doi.org/10.1017/S0950268800057289

[25] Anderson, E.C., Doughty, W.J., Anderson, J. and Paling, R. (1979) The Pathogenesis of Foot-and-Mouth Disease in the African Buffalo (Syncerus caffer) and the Role of this Species in the Epidemiology of the Disease in Kenya. Journal of Comparative Pathology, 89, 541-549. https://doi.org/10.1016/0021-9975(79)90045-8

[26] Ayebazibwe, C., Mwiine, F.N., Tjornehoj, K., Balinda, S.N., Muwanika, V.B., Ademun Okurut, A.R., Belsham, G.J., Normann, P., Siegismund, H.R. and Alexandersen, S. (2010) The Role of African Buffalos (syncerus caffer) in the Maintenance of Foot-and-Mouth Disease in Uganda. BMC Veterinary Research, 6, 54.

https://doi.org/10.1186/1746-6148-6-54

[27] Bastos, A.D., Boshoff, C.I., Keet, D.F., Bengis, R.G. and Thomson, G.R. (2000) Natural Transmission of Foot-and-Mouth Disease Virus between African Buffalo (Syncerus caffer) and Impala (Aepyceros melampus) in the Kruger National Park, South Africa. Epidemiology and Infection, 124, 591-598. https://doi.org/10.1017/S0950268899004008

[28] Bronsvoort, B.M., Parida, S., Handel, I., McFarland, S., Fleming, L., Hamblin, P. and Kock, R. (2008) Serological Survey for Foot-and-Mouth Disease Virus in Wildlife in Eastern Africa and Estimation of Test Parameters of a Nonstructural Protein Enzyme-Linked Immunosorbent Assay for Buffalo. Clinical and Vaccine Immunology, 15, 1003-1011. 
https://doi.org/10.1128/CVI.00409-07

[29] Dawe, P.S., Flanagan, F.O., Madekurozwa, R.L., Sorensen, K.J., Anderson, E.C., Foggin, C. M., Ferris, N.P. and Knowles, N.J. (1994) Natural Transmission of Foot-and-Mouth Disease Virus from African Buffalo (Syncerus caffer) to Cattle in a Wildlife Area of Zimbabwe. Veterinary Record, 134, 230-232. https://doi.org/10.1136/vr.134.10.230

[30] Hedger, R.S., Condy, J.B. and Gradwell, D.V. (1980) The Response of Some African Wildlife Species to Foot-and-Mouth Disease Vaccination. Journal of Wildlife Diseases, 16, 431438. https://doi.org/10.7589/0090-3558-16.3.431

[31] Thomson, G.R., Vosloo, W. and Bastos, A.D. (2003) Foot and Mouth Disease in Wildlife. Virus Research, 91, 145-161. https://doi.org/10.1016/S0168-1702(02)00263-0

[32] Thomson, G.R., Vosloo, W., Esterhuysen, J. and Bengis, R.G. (1992) Maintenance of Foot and Mouth Disease Viruses in Buffalo (Syncerus caffer Sparrman, 1779) in Southern Africa. Revue Scientifique et Technique, 11, 1097-1107. https://doi.org/10.20506/rst.11.4.646

[33] Pinto, A.A. (2004) Foot-and-Mouth Disease in Tropical Wildlife. Annals of the New York Academy of Sciences, 1026, 65-72. https://doi.org/10.1196/annals.1307.008

[34] Chilonda, P., Woodford, J.D., Ahmadu, B., Samui, K.L., Syakalima, M. and Mlangwa, J.E. (1999) Foot and Mouth Disease in Zambia: A Review of the Aetiology and Epidemiology and Recommendations for Possible Control. Revue Scientifique et Technique, 18, 585-592. https://doi.org/10.20506/rst.18.3.1182

[35] Ganter, M., Graunke, W.D., Steng, G. and Worbes, H. (2001) Foot and Mouth Disease in Sheep and Goats. Deutsche Tierarztliche Wochenschrift, 108, 499-503.

[36] Anderson, E.C., Doughty, W.J. and Anderson, J. (1976) The Role of Sheep and Goats in the Epizootiology of Foot-and-Mouth Disease in Kenya. Journal of Hygiene, 76, 395-402. https://doi.org/10.1017/S0022172400055315

[37] Maddur, M.S., Kishore, S., Gopalakrishna, S., Singh, N., Suryanarayana, V.V. and Gajendragad, M.R. (2009) Immune Response and Viral Persistence in Indian Buffaloes (Bubalus bubalis) Infected with Foot-and-Mouth Disease Virus Serotype Asia 1. Clinical and Vaccine Immunology, 16, 1832-1836. https://doi.org/10.1128/CVI.00302-09

[38] Konkobo, P.B.I.K. (2009) Modélisation bayésienne spatio-temporelle des foyers de fièvre aphteuse au Burkina-Faso de 2004-2008. IMTA. Thèse de Master en Santé Animale Tropicale 108, 1-22.

[39] Hedger, R.S. and Condy, J.B. (1985) Transmission of Foot-and-Mouth Disease from African Buffalo Virus Carriers to Bovines. Veterinary Record, 117, 205.

https://doi.org/10.1136/vr.117.9.205-a 
Submit or recommend next manuscript to SCIRP and we will provide best service for you:

Accepting pre-submission inquiries through Email, Facebook, LinkedIn, Twitter, etc. A wide selection of journals (inclusive of 9 subjects, more than 200 journals) Providing 24-hour high-quality service

User-friendly online submission system

Fair and swift peer-review system

Efficient typesetting and proofreading procedure

Display of the result of downloads and visits, as well as the number of cited articles Maximum dissemination of your research work

Submit your manuscript at: http://papersubmission.scirp.org/

Or contact ojas@scirp.org 